\title{
Investigating the relationship between wind erosion and value of animal habitats in desert areas
}

\author{
${ }^{* 1}$ S. M. Azarkar, ${ }^{2}$ H. Ahmadi, ${ }^{2}$ N. Khorasani and ${ }^{2}$ M. Karami \\ ${ }^{1}$ Department of Environmental Science, Graduate School of the Environment and Energy, Islamic Azad University, \\ Science and Research Campus, Tehran, Iran \\ ${ }^{2}$ Department of Natural Resources, Tehran University, Tehran, Iran \\ Received 5 June 2005; $\quad$ revised 2 July 2005; $\quad$ accepted 15 November $2005 \quad$ available online 22September 2005
}

\begin{abstract}
Animal species in desert habitats are taken into consideration because of their uniqueness and inherent value. However the added pressures from climate and human have made living conditions difficult and acute for them. Wind erosion is one of the common phenomena in desert areas; this phenomenon can affect biotic value of those areas. Climatic constraints along with human development in such areas result in enhancing the effect of wind erosion, and as a result, affect the value of animal habitats. Therefore, by estimating the rate of wind erosion in such areas, the capability of environment for providing appropriate conditions for animal species' subsistence can also be estimated. The objective of this research is to find the relation between the rate of wind erosion and value of animal habitat in Sarakhs as a representative of Razavi Khorasan Province. This research has been carried out in four steps: a) Approximate identification of each animal habitat in the area. b) Estimating the wind erosion based on IRIFR model. c) Estimating the approximate value of each of the animal habitats in the area. d) Determining the correlation between the value of each animal habitat with the average rate of wind erosion in that habitat. Investigating the relation between the average rate of wind erosion and the value of animal habitats which indicates that there is a significant correlation between them, that is to say, effective factors in increasing the rate of wind erosion have affected the quality of animal habitats, and proportional to their intensity, decreased the value of habitat.
\end{abstract}

Key words: Animal habitats, wind erosion, IRIFR model, Sarakhs region

*Corresponding Author,E-mail: azarkar1344@yahoo.com

\section{INTRODUCTION}

Two Thirds of Iran is arid and semiarid, some 450,000 $\mathrm{Km}^{2}$ of which constitute deserts (Ahmadi, 1998). Wind erosion in desert, owing to the poor vegetation, lack of physical features, and shortage of humidity are among the most common phenomena. The wide expanse of desert areas, on the one hand, and the existence of valuable animal and plant species living in those deserts (Mozaffarian, 1998). On the other hand, demands more scientific considerations, because the pressure of nature due to climatic and edaphic limitations along with profiteers' exploitation of the natural resources of the region have made survival circumstances very difficult for the animals settling there, and have been leading them to extinction. The animal and plant species of the deserts are mainly among the unique ones, which with high passivity potential, endure desert unbearable circumstances, and have adapted to the least possibilities, and continue their existence with the imminence of extinction.
(Madjnoonian, 2000). For this very reason, they are very sensitive and vulnerable. Estimation of wind erosion by means of IRIFR (Iran Research Institute of Forests and Rangelands), model is one way to determine the rate of wind erosion in desert areas (Ekhtesasi and Ahmadi, 1994). By using this procedure, it is possible to determine the parameters involve in wind erosion, and it gives points to each (based on their respective Tables 1 and 2), and estimates the rate of wind erosion within each region, at issue, in terms of ton/ha/y. Consideration of wind erosion in desert areas bears importance for a dual reason: a) The phenomenon of wind erosion can affect all aspects of life, and disorder or stop the natural trend of life of the existent species of desert areas. (Rafahi, 1999). b) The severity of wind erosion action in desert areas is in close correlation with physical factors (velocity and direction of regional wind, precipitation rate, vegetation density, pedological and topographical characteristics) 
and with human activities (overgrazing, uprooting bushes, tillage, road making), in such a way that almost all factors that cause the erosion to increase can put a negative impact on the existent species, specifically, animals. As a result, the severity of wind erosion bears a significant relationship to the destruction of animal habitats. Accordingly, it is possible to estimate the destruction rate of animal habitats in the deserts, based on determining the wind erosion rate and calculating the correlation between the two. This research is performed at Sarakhs region of Razavi Khorasan Province in 2003.

\section{MATERIALS AND METHODS}

The region under consideration in, 243000 ha in area, situated in the domain of Sarakhs city at the farthest end of north-eastern part of Iran (Fig. 1). Valuable animal species such as Persian wild ass (Equas hemionus onager), Gazelle (Gazella subgutturosa), Caracal (felis caracal) and Wild cat (felis silvestris ) have been living within the habitats of the region (Feh et al., 2004 and Baillie et al., 2004) some of which have migrated or become extinct for a variety of reasons. (Atamuradov et al., 1999 and Caughley, 1994). In order to determine the relationship between the rate of wind erosion in Sarakhs region and that of the destruction of animal species habitats within that zone, the following measures have been taken.

The mammals selected for the research are representative of animals because of their known territories, large size and being easy to study. By means of field observations, valid available accounts at Sarakhs Department of Environment, scientific references (Firouz, 2000 and Ziaie, 1996) and provision of questionnaires, data from local people, the approximate territory of animal habitats of the region was determined.

Experimental model of IRIFR has been propounded, for the first time, by Ekhtesasi and Ahmadi (Ahmadi, 1998). This method is based on the scoring of 9 geomorphological factors. The score of each factor in Table 1 is studied and calculated for each of the geomorphological facies. The algebraic sum of them is the score of that facies and represents the condition of wind erosion in it. Table 2 shows the displacement of wind erosion in that facies can be estimated. On the basis of the regional map of morphology, the sphere of each facies was distinguished and the impact of 9 factors of wind erosion was rated and scored, and commensurate to the strength or weakness of each factor and its influence on sedimentation, a point (based on their respective Tables 1 and 2) was assigned to it.

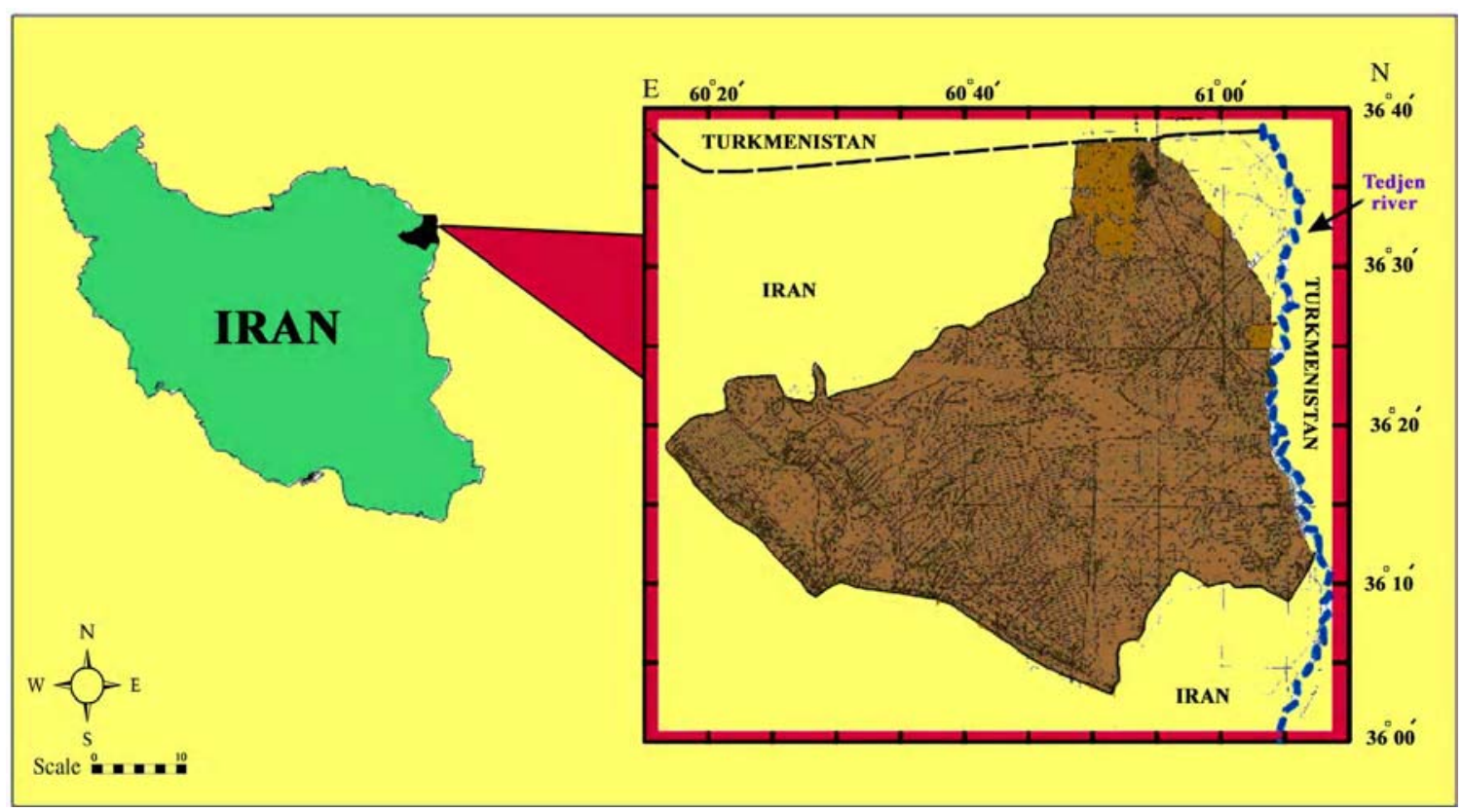

Fig 1: The location of Sarakhs region in Iran 
The algebraic sum of the figures obtained out of the 9 factors within each facies is suggestive of the severity of its wind erosion. These factors consist of petrology, lands morphology and their topography, velocity and quality of the wind, soil and topsoil, the density of the vegetation, erosive effects of soil surface, soil dampness, type and dispersion of eolian deposits, and land use management.

\section{RESULTS}

Fig. 2 indicates the approximate territory of animal habitats of the region in question. This map includes the habitat spheres of existent and non-existent species. The species of Asian wild ass is among the valuable animal species, which has not been beheld during the last 15 years, but other animal species with a few sporadic numbers are still visible.

Table 1: Definition of erosion class and estimation of sediment discharge of wind erosion by means of IRIFR.E.A model

\begin{tabular}{|clll|}
\hline $\begin{array}{c}\text { Erosion } \\
\text { class }\end{array}$ & \multicolumn{1}{c}{$\begin{array}{c}\text { Rate of } \\
\text { erosion }\end{array}$} & $\begin{array}{c}\text { Sum of } \\
\text { calculated } \\
\text { scores }\end{array}$ & $\begin{array}{c}\text { Sediment } \\
\text { discharge } \\
\text { (ton/ha/y) }\end{array}$ \\
\hline I & Little & Less than 25 & Less than 2.5 \\
\hline II & Low & $50-25$ & $2.5-5$ \\
\hline III & Medium & $50-75$ & $5-15$ \\
\hline IV & High & $75-100$ & $15-60$ \\
\hline V & Very high & More than 100 & More than 60 \\
\hline
\end{tabular}

By the help of IRIFR Model, and rating and scoring the 9 effective factors in wind erosion, Table 3 was prepared. Within this table the points for each of the 22 geomorphological facies in the region, at issue, were calculated, and their erosion class was defined, and on the basis of these points, the regional isoerosive Fig. 3 was depicted. Within this Figure five classes of wind erosion have been defined. In order to valuate animal habitats of the region roughly, an approach of scoring the effective agents in improving quality has been devised. The most important of these factors are food and water supply, and safety (human influences) that after field observations and gathering data commensurate to the status of each agent a score ranging from 0 to 10 have been assigned to it.

Table 2: The method of scoring for wind erosion factors by the help of IRIFR. model

\begin{tabular}{|lc|}
\hline \multicolumn{1}{|c|}{ Factor } & $\begin{array}{c}\text { Range of } \\
\text { score }\end{array}$ \\
\hline Petrology & $0-10$ \\
Land morphology & $0-10$ \\
Velocity and quality of the wind & $0-20$ \\
Soil and its surface & $-5-15$ \\
Density of vegetation & $-5-15$ \\
Erosive effects of soil surface & $-5-20$ \\
Soil dampness & $0-10$ \\
Type and dispersion of aeolian deposits & $0-10$ \\
Land use management & $-5-15$ \\
\hline
\end{tabular}

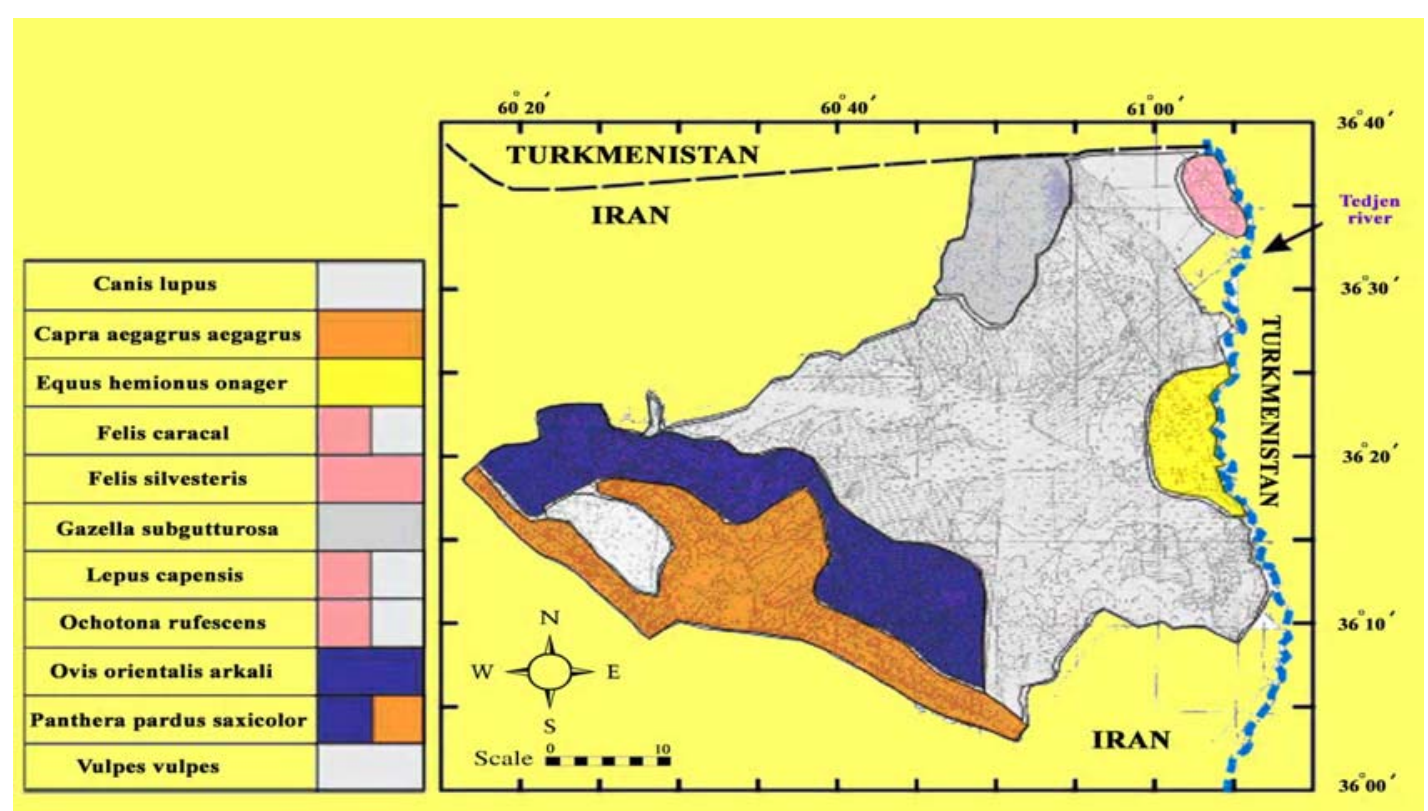

Fig 2: The lestimated territory of animal species habitat in Sarakhs region 
Table 3: The estimation of wind erosion rate by the help of IRIFRE. A model in Sarakhs region

\begin{tabular}{|c|c|c|c|c|c|c|c|c|c|c|c|c|}
\hline 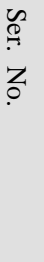 & 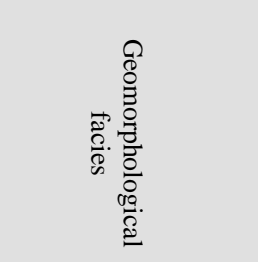 & 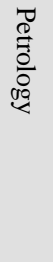 & $\begin{array}{l}0 \\
0 \\
0 \\
0 \\
0 \\
0 \\
0 \\
0 \\
0 \\
0 \\
0 \\
0\end{array}$ & $\sum_{\vdots}$ & 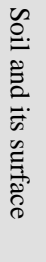 & 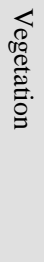 & $\begin{array}{l}\text { M } \\
\stackrel{7}{0} \\
0 \\
\omega \\
0 \\
0 \\
0 \\
0 \\
0 . \\
0\end{array}$ & 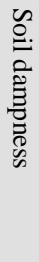 & 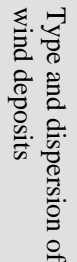 & 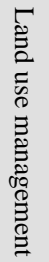 & $\begin{array}{l}\tilde{\omega} \\
\vdots \\
0 \\
0 \\
\tilde{\omega} \\
0 \\
0 \\
0 \\
*\end{array}$ & 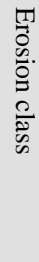 \\
\hline 1 & Rock mass & 3 & 0 & 5 & -2 & 0 & 0 & 3 & 0 & 10 & 19 & I \\
\hline 2 & Sea-coarse & 3 & 1 & 5 & -2 & -5 & -3 & 3 & 1 & 11 & 14 & I \\
\hline 3 & Rock outcrop & 4 & 0 & 5 & 0 & 0 & -2 & 3 & 1 & 11 & 22 & I \\
\hline 4 & $\begin{array}{l}\text { Rock outcrop with } \\
\text { debris }\end{array}$ & 5 & 3 & 7 & 1 & -5 & -1 & 2 & 1 & 12 & 25 & II \\
\hline 5 & Crag & 5.5 & 2 & 6 & 0 & 0 & 1 & 2 & 0 & 10 & 26.5 & II \\
\hline 6 & Crag with debris & 5.5 & 3 & 7.5 & 1 & 2 & 3 & 5 & 1 & 11 & 39 & II \\
\hline 7 & Slight rill erosion & 6 & 3 & 7 & 4 & 4 & 4 & 5 & 2 & 12 & 47 & II \\
\hline 8 & Dissolutional erosion & 3 & 3 & 7 & 3 & -2 & 4 & 6 & 2 & 9 & 35 & II \\
\hline 9 & $\begin{array}{l}\text { Bad-land and } \\
\text { Dissolutional erosion }\end{array}$ & 6 & 4.5 & 9 & 5 & -2 & 6 & 5 & 3 & 8 & 44.5 & II \\
\hline 10 & Water Erosion & 5 & 4 & 10 & 4 & -2 & 5 & 2 & 3 & 5 & 36 & II \\
\hline 11 & Coarse debris & 4 & 5 & 11 & 0 & 4 & 2 & 3 & 4 & 10 & 43 & II \\
\hline 12 & Gully erosion & 9 & 6 & 14 & 2 & -2 & 4 & 5 & 3 & 7.5 & 48.5 & II \\
\hline 13 & Irregular slope & 9 & 6 & 15 & 6 & 4 & 5 & 6 & 3 & 11 & 65 & III \\
\hline 14 & Alluvial fan & 8 & 6 & 15 & 3 & 4 & 5 & 8 & 3.5 & 8 & 60.5 & III \\
\hline 15 & $\begin{array}{l}\text { Alluvium of medium } \\
\text { grains }\end{array}$ & 6 & 7 & 13 & 2 & 4 & 6 & 7 & 3 & 8 & 56 & III \\
\hline 16 & $\begin{array}{l}\text { Alluvium of fine } \\
\text { grains }\end{array}$ & 7 & 7.5 & 18 & 6 & 8 & 8 & 6 & 4 & 12 & 76.5 & IV \\
\hline 17 & $\begin{array}{l}\text { Alluvium of coarse } \\
\text { grains }\end{array}$ & 4 & 7.5 & 14 & 5 & 7 & 6 & 8 & 3 & 8 & 62.5 & III \\
\hline 18 & Side erosion & 5 & 8.5 & 16 & 8 & -5 & 7 & 3 & 4 & 13 & 59.5 & III \\
\hline 19 & Sand dunes & 9 & 9 & 18 & 13 & 7 & 18 & 7 & 8 & 13 & 102 & V \\
\hline 20 & Sand beds & 9 & 9 & 18 & 14 & 7 & 18 & 5 & 7 & 14 & 101 & V \\
\hline 21 & Wind erosion & 9 & 9.5 & 19 & 15 & 4 & 18 & 5 & 6 & 13 & 98.5 & IV \\
\hline 22 & Argillaceous area & 9.5 & 10 & 19 & 15 & 0 & 18 & 3 & 6 & 8 & 88.5 & IV \\
\hline
\end{tabular}

*With attention to the factors presented in Table 2, a certain point has been assigned to each erosion facies the sums of which represent the condition of wind erosion on it.

These scores are relative and have comparative values. The algebraic sum of scores for each habitat indicates its approximate value (Table 4). The relation between wind erosion and of fauna's habitats depending on the value of the species existing there, animal habitats of desert areas take on special importance. Furthermore, the factors responsible for the destruction of these habitats are mainly those, which aggravate the effect of wind erosion. Thus, there is a correlation between agents bearing upon reducing thevalue of each animal habitat and the factors affecting wind erosion. The result derived from this research lends support to this hypothesis, and has managed to estimate the type and rate of statistical connection between wind erosion, and the value of habitats. Fig. 4 has been delineated based on Table 4. In Fig. 4 a linear reverse correlation is observable between the rate of wind erosion and the value of habitat:

$V_{H}=26-0.17\left(E_{C}\right), r=-0.94$

$V_{H}=$ The value of habitat, and

$E_{C}=$ The calculated score for each facies within Table 4.

Added to this, for a better explication of the relationship, the calculated scores within Table 4 have been turned into (ton/ha/y) values for the deposits due to wind erosion, which are presented in Fig. 5. In this Figure a logarithmic reverse correlation has been 
Investigating the relationship...

obtained between wind erosion content and habitat value:

$V_{H}=24.7-3.8 \ln \left(E_{C}\right), r=-0.93$

\section{DISCUSSION AND CONCLUSSION}

The results obtained from equations Nos. 1 and 2 suggest that there is a significant correlation between wind erosion and value of animal habitats in Sarakhs. This means that as the rate of wind erosion increases, the quality of habitats and also its ability to provide optimal conditions for the survival of species animal decrease. Therefore, all factors that cause the influence of wind erosion to increase are also the factors of animal habitats deterioration.

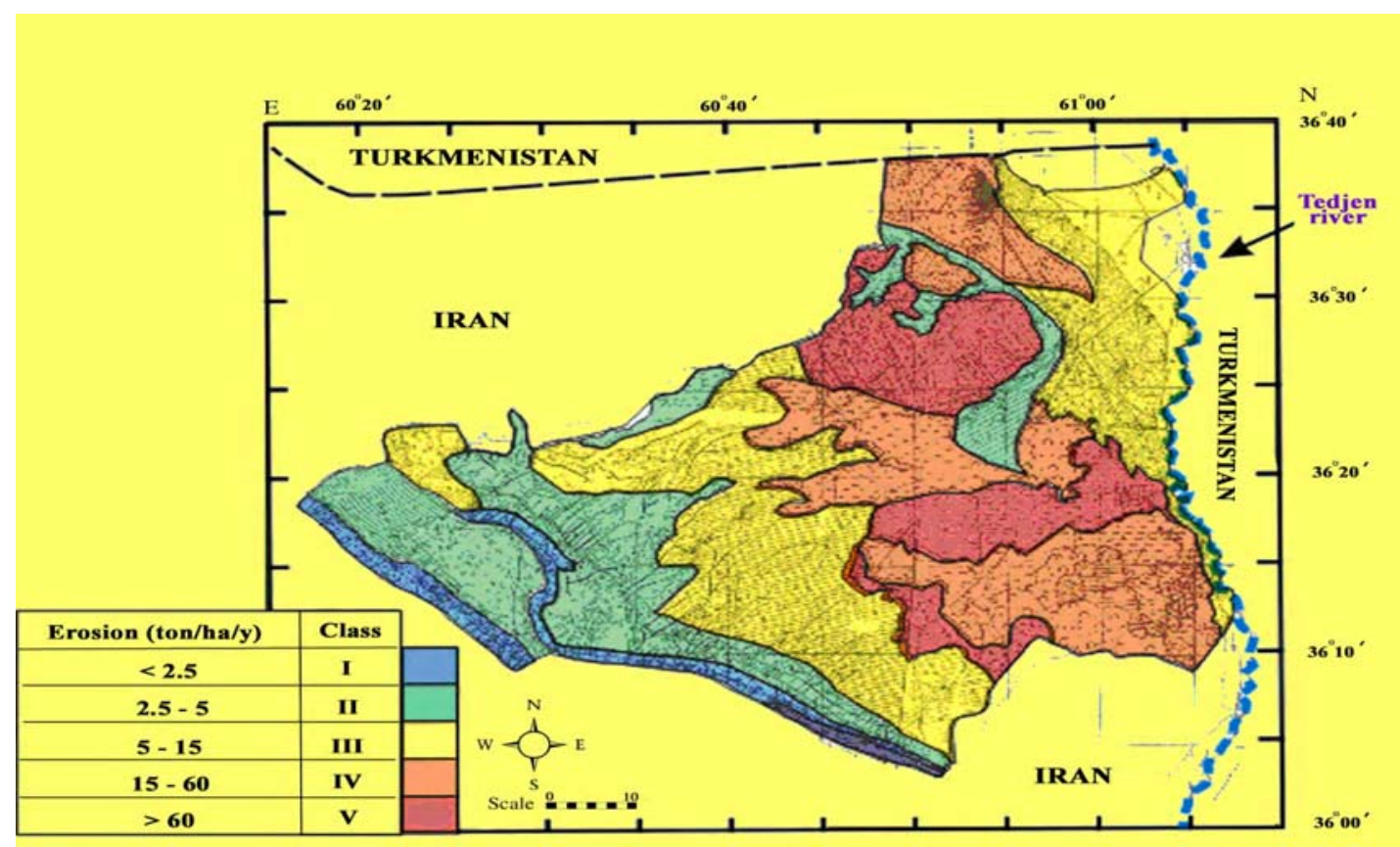

Fig 3: The estimation of wind erosion in Sarakhs region

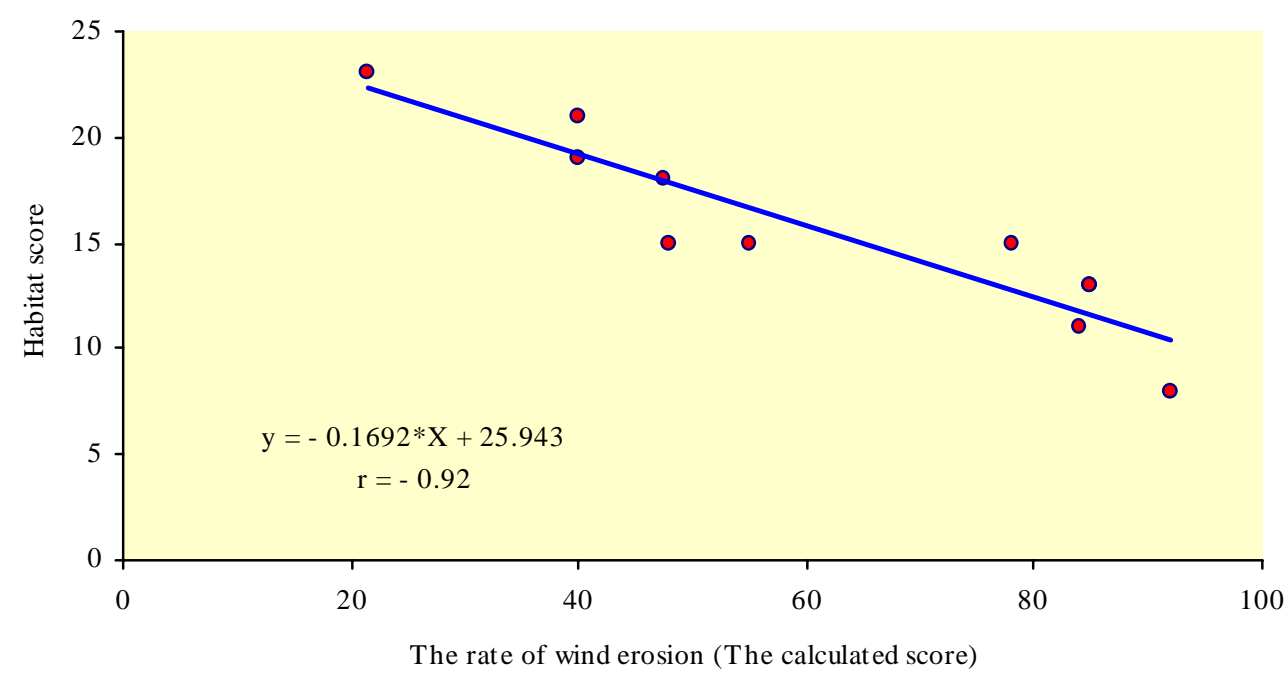

Fig. 4: The relation between the rate of wind erosion and habitat score in Sarakhs region 
S. M. Azarkar, et al.

Table 4: The Estimation of the wind erosion rate in the habitats of Sarakhs region

\begin{tabular}{|c|c|c|c|c|c|c|c|c|c|c|}
\hline \multirow{3}{*}{ 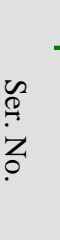 } & \multicolumn{2}{|c|}{ Animal species } & \multirow{3}{*}{$\begin{array}{l}\text { Geomorphological } \\
\text { facies }\end{array}$} & \multicolumn{6}{|c|}{ Habitat status } & \multirow{3}{*}{$\begin{array}{l}\text { Estimation } \\
\text { of } \\
\text { wind } \\
\text { erosion } \\
\text { rate ** }\end{array}$} \\
\hline & \multirow{2}{*}{$\begin{array}{l}\text { Scientific } \\
\text { name }\end{array}$} & \multirow[b]{2}{*}{ Name } & & \multirow{2}{*}{$\begin{array}{l}\text { Average } \\
\text { altitude } \\
\text { from sea } \\
\text { level (m) }\end{array}$} & \multirow[b]{2}{*}{$\begin{array}{c}\text { Dominant } \\
\text { Phytospecies }\end{array}$} & \multicolumn{4}{|c|}{ Score } & \\
\hline & & & & & & $\begin{array}{l}\text { T1 } \\
\stackrel{2}{2}\end{array}$ & 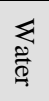 & 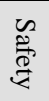 & $\tilde{G}_{*}^{\infty}$ & \\
\hline 1 & $\begin{array}{c}\text { Gazella } \\
\text { subgutturo } \\
\text { sa }\end{array}$ & $\begin{array}{l}\text { Goitred } \\
\text { Gazelle }\end{array}$ & $\begin{array}{l}\text { Argillaceous area } \\
\text { Sand dunes } \\
\text { Wind erosion }\end{array}$ & 395 & $\begin{array}{l}\text { Goebelia sp. } \\
\text { Haloxylon sp. }\end{array}$ & 3 & 3 & 2 & 8 & 92 \\
\hline 2 & $\begin{array}{l}\text { Capra } \\
\text { aegagrus } \\
\text { aegagrus }\end{array}$ & $\begin{array}{l}\text { Wild } \\
\text { Goat }\end{array}$ & $\begin{array}{l}\text { Crag with debris } \\
\text { Rock mass and sea } \\
\text { coarse } \\
\text { Rock outcrop with } \\
\text { debris }\end{array}$ & 927 & $\begin{array}{l}\text { Artemisia sp. } \\
\text { Pistacia atlantica } \\
\text { Amygdalus } \\
\text { lycioides }\end{array}$ & 7 & 8 & 8 & 23 & 21.5 \\
\hline 3 & $\begin{array}{l}\text { Ochotona } \\
\text { rufescens }\end{array}$ & Pika & $\begin{array}{l}\text { Wind erosion } \\
\text { Plateau } \\
\text { Stabilized sand dunes }\end{array}$ & 340 & $\begin{array}{l}\text { Goebelia sp. } \\
\text { Haloxylon sp. }\end{array}$ & 5 & 7 & 3 & 15 & 78 \\
\hline 4 & $\begin{array}{l}\text { Panthera } \\
\text { pardus } \\
\text { saxicolor }\end{array}$ & Leopard & $\begin{array}{l}\text { Erosional Plateau } \\
\text { Alluvial fan } \\
\text { Crag } \\
\text { Regular slope }\end{array}$ & 575 & $\begin{array}{l}\text { Poa bulbosa } \\
\text { Artemisia sp. } \\
\text { Astragalus } \\
\text { gossypinus }\end{array}$ & 6 & 7 & 5 & 18 & 47.5 \\
\hline 5 & $\begin{array}{l}\text { Lepus } \\
\text { capensis }\end{array}$ & $\begin{array}{l}\text { Cape } \\
\text { Hare }\end{array}$ & Most facies of the plain & 400 & $\begin{array}{l}\text { Artemisia sp. } \\
\text { Poa bulbosa } \\
\text { Haloxylon sp. } \\
\text { Tamarix stricta } \\
\text { Alhagi camelorum }\end{array}$ & 7 & 7 & 7 & 21 & 40 \\
\hline 6 & $\begin{array}{l}\text { Vulpes } \\
\text { vulpes }\end{array}$ & $\begin{array}{l}\text { Common } \\
\text { Fox }\end{array}$ & Most facies of the plain & 400 & $\begin{array}{l}\text { Artemisia sp. } \\
\text { Poa bulbosa } \\
\text { Haloxylon sp. } \\
\text { Tamarix stricta } \\
\text { Alhagi } \\
\text { camelorum }\end{array}$ & 7 & 6 & 6 & 19 & 40 \\
\hline 7 & $\begin{array}{l}\text { Ovis } \\
\text { orientalis } \\
\text { arkali }\end{array}$ & $\begin{array}{l}\text { Wild } \\
\text { sheep } \\
\text { (Urial) }\end{array}$ & $\begin{array}{l}\text { Erosional Plateau } \\
\text { Alluvial fan } \\
\text { Crag } \\
\text { Regular slope }\end{array}$ & 450 & $\begin{array}{l}\text { Alhagi comelorum } \\
\text { Poa bulbosa } \\
\text { Artemisia sp. }\end{array}$ & 6 & 7 & 2 & 15 & 55 \\
\hline 8 & $\begin{array}{l}\text { Felis } \\
\text { caracal }\end{array}$ & Caracal & $\begin{array}{l}\text { Sand dunes } \\
\text { Plateau }\end{array}$ & 368 & $\begin{array}{l}\text { Convolvulus } \\
\text { chondrilloides } \\
\text { Alhagi } \\
\text { comelorum } \\
\text { Tamarix stricta }\end{array}$ & 4 & 5 & 4 & 13 & 85 \\
\hline 9 & $\begin{array}{c}\text { Felis } \\
\text { silvesteris }\end{array}$ & $\begin{array}{l}\text { Wild } \\
\text { Cat }\end{array}$ & $\begin{array}{l}\text { Sand dunes } \\
\text { Plateau }\end{array}$ & 368 & $\begin{array}{l}\text { Convolvulus } \\
\text { chondrilloides } \\
\text { Alhagi } \\
\text { comelorum } \\
\text { Tamarix stricta }\end{array}$ & 5 & 4 & 4 & 13 & 85 \\
\hline 10 & $\begin{array}{l}\text { Canis } \\
\text { lupus }\end{array}$ & Wolf & $\begin{array}{l}\text { Most facies of the } \\
\text { plain }\end{array}$ & 400 & $\begin{array}{l}\text { Artemisia sp. } \\
\text { Poa bulbosa } \\
\text { Haloxylon sp. } \\
\text { Tamarix stricta } \\
\text { Alhagi comelorum }\end{array}$ & 6 & 5 & 4 & 15 & 58 \\
\hline 11 & $\begin{array}{l}\text { Equus } \\
\text { hemionus } \\
\text { onager }\end{array}$ & $\begin{array}{l}\text { Persian } \\
\text { Wild } \\
\text { Ass }\end{array}$ & $\begin{array}{l}\text { Plateau } \\
\text { Sand dunes } \\
\text { Wind erosion }\end{array}$ & 360 & $\begin{array}{l}\text { Convolvulus } \\
\text { chondrilloides } \\
\text { Tamarix stricta } \\
\text { Alhagi } \\
\text { comelorum }\end{array}$ & 5 & 4 & 2 & 11 & 84 \\
\hline
\end{tabular}

* The sum of points for the triple factors of food, water and safety.

** The means of wind erosion rate to the habitat of each animal species lying within a few geomorphological facies. 
Investigating the relationship...

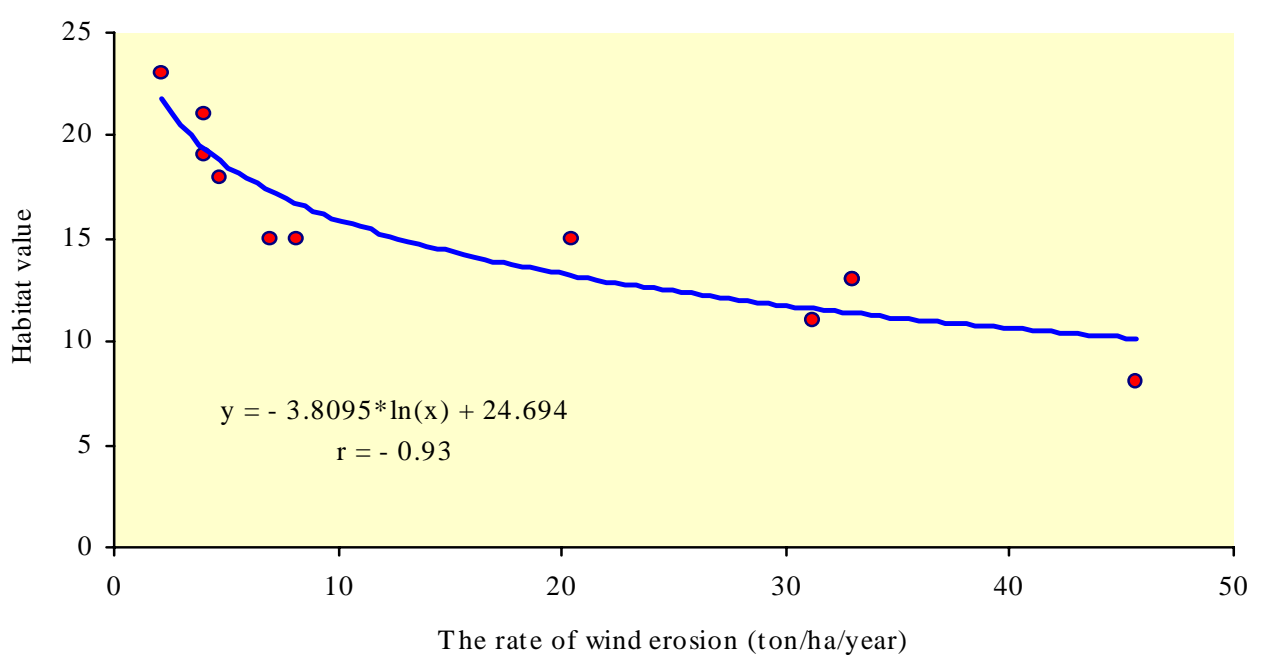

Fig. 5: The relation between the rate of wind erosion and habitat value in Sarakhs region

As a result, controlling wind erosion can provide better conditions for survival of animal. Given that wind erosion is one of the characteristics of desert areas. We can use this method for other desert areas in Iran including Razavi Khorasan Province. Applicability, reduced expenses of valuation, needlessness of specific man power, and specialtyin the affair of evaluating wildlife, are among the merits enabling the team of valuers to evaluate the overall situation of desert habitats by the help of the data and maps specific to each desert area.

\section{ACKNOWLEDGEMENT}

The authors would like to appriciate the collaborations of Mr. Sayyed Mohammad Tabatabai, the Hon. administrator to the Center of Research for Natural Resources and Domesticated Animals’ Affairs in Razavi Khorasan Agriculture Jihad, and Mr. Ali Shirmohammadi, the Bureau for Stabilizing Running Sands in Razavi Khorasan General Administration of Natural Resources and finally Mr. Sepehri the Chairman to Sarakhs Office of Environment Protection.

\section{REFERENCES}

Ahmadi, H., (1998). Applied Geomorphology, (Desert - wind erosion), Tehran University Publication, 23, 85-395.

Atamuradov, H., Fet, G. N., Fet, V., Valdez, R. and Feldman, W., (1999). Biodiversity, genetic diversity, and projected areas in Turkmenistan, J. Sustain. Forest. 9 (1-2), 73-88.
Baillie, J. E. M., Hilton-Taylor, C. and Stuart, S. N., (2004). IUCN Red List of Threatened Species. A Global Species Assessment. IUCN, Gland, Switzerland and Cambridge, UK, Available at: http:/ /www.iucn.org/themes/ssc/red_list_2004/ main_EN.htm.

Caughley, G. and Sinclair, A. R. E., (1994). Wildlife ecology and management, Blackwell Scientific Publications. Oxford, 270-293.

Feh, C., Shah, N., Rowen, M., Reading, R. and Goyal, S. P., (2004). Status and action plan for the asiatic wild ass (Equus hemionus), IUCN, Gland, Switzerland and Cambridge, UK, 2004, Available at: http://www.iucn.org/themes/ssc/actionplans/ equids/part2chapter5.pdf.

Firouz, E., (2000). A guide to the fauna of Iran. Iran University Press, 339-414.

Madjnoonian, H., (2000). Protected Areas of Iran. Department of the Environment, Iran, 20-73.

Mozaffarian, V., (1998). A Dictionary of Iranian Plants Names, Farhang e Moaser Publication.

Rafahi, H. Gh., (1999). Wind erosion and conservation, Tehran University Publication, 5372.

Ziaie, H., (1996). A field guide to the mammals of Iran, Department of the Environment Publication, 183272. 